\title{
Social Sustainability in Modelling of Value Creation in Housing Refurbishment
}

\author{
Søren Wandahl \\ Department of Engineering, Aarhus University, Aarhus, Denmark \\ Louise Lund \\ Implenia, Bayern, Germany \\ Hasse Neve \\ Department of Engineering, Aarhus University, Aarhus, Denmark
}

\begin{abstract}
Purpose - The aim of this study is to develop a framework that incorporates social aspects of housing refurbishment when evaluating the sustainability of refurbishment projects. The research examined whether the German Sustainable Building Council (DGNB) certification yields a holistic approach to social sustainability.

Approach - A framework for social sustainability was established from values identified through reviews of certification systems, published literature and from interviews. The target is to better assess and value holistic and soft parameters like social sustainability when assessing the overall value creation of projects.

Findings - The result was a more transparent and systematic structure, which revealed that the DGNB certification had shortcomings in a holistic approach to social sustainability. Counteractions for these shortcomings are discussed.

Research Limitations - Researchers are still discussing how to include more soft aspects like social aspects with the more hard measures like energy consumption and initial cost in the same equation for addressing sustainability in a more holistic framework. This research contributes to this.

Practical Implications - Considering the current climate situation and the amount and the state of existing European building stock, sustainable renovation is inevitable. In Europe, the DGNB certification is one of the most applied certification systems of sustainability. It approaches all parts of sustainability. Yet, social sustainability has been criticised for being neglected.

Originality/Value - A review of literature concerning the concept suggests that it is a concept in chaos. There have been a number of attempts to impose some order to this; however, the attempts have all been made differently and with limited success.
\end{abstract}

Keywords Social sustainability, Indicators, Values, Certification, Refurbishment, Holistic

All papers within this proceedings volume have been peer reviewed by the scientific committee of the 10th Nordic Conference on Construction Economics and Organization (CEO 2019).

(C) Søren Wandahl, Louise Lund, Hasse Neve. Published in the Emerald Reach Proceedings Series. Published by Emerald Publishing Limited. This article is published under the Creative Commons Attribution (CC BY 4.0) licence. Anyone may reproduce, distribute, translate and create derivative works of this article (for both commercial and non-commercial purposes), subject to full attribution to the original publication and authors. The full terms of this licence may be seen at http:// creativecommons.org/licences/by/4.0/legalcode

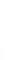


10th Nordic Conference Tallinn

\section{Introduction}

Today's environment is gradually collapsing and will keep on doing so if actions are not taken to prevent it. Approximately 40 per cent of the total energy use and one-third of global greenhouse gas is emitted from the construction industry (Ahn, et al., 2010). Taking the massive existing European building stock into consideration (Harling \& Petersen, 2016), where more than 40 per cent of the European existing building stock is more than 50 years old (Kylili, et al., 2016) it becomes clear that it is not enough only to think sustainability when building new, but also during refurbishment.

Assessment methods of sustainability in buildings have been widely developed since 1990 when the first assessment tool Building Research Establishment Environmental Assessment Method (BREEM) (BREEAM, 2016) was published. This was followed by other first generation methods from other countries. Common for the first-generation assessment tools are that they mainly focus on environmental sustainability. The second-generation assessment tools such as German Sustainable Building Council (DGNB) has a more holistic approach by also focusing on social and economic aspects, however, the system is a rather complicated system and requires a significant amount of technical data (Marjaba \& Chidiac, 2016). In a larger review of 43 of the current certification systems carried out by Nielsen et al. (2016), it was found that 40 per cent of the assessed certification systems were considering all three parts of sustainability. The same review concludes that the social part of sustainability was the least included part (63 per cent).

A review of literature on social sustainability suggests that it is a concept in chaos and there have been a number of attempts to impose some order to this (Vallance, et al., 2011). However, as social sustainability is qualitative in nature, the attempts have all been made by using different methods to define it. Kylili et al. (2016) use a five-point Likert scale to assess social sustainability in renovation projects. Acre \& Wyckmans (2014) and Ahmad \& Jamaluddin (2016) use quantitative findings related to a framework for social sustainability set up by each pair of authors in an attempt to quantify social sustainability. Vibæk Jensen \& Beim (2006) and Nygaard (2000) have taken qualitative approaches in order to define a toolset to ensure the architectonic quality as a part of social sustainability.

The aim of this research was to analyse and examine if the DGNB certification yields a holistic approach to social sustainability in dwelling renovation in Denmark. When shortcomings were identified, optimisation of the certification and new indicators were developed to eliminate these shortcomings.

\section{Method}

To gain experience with the DGNB certification system, a test screening of a real renovation project was performed in correspondence with a certified DGNB auditor. This is not further included in the paper as the purpose was only to gain experience with DGNB. To gain additional knowledge about the current status of social sustainability, five interviews were conducted with primary stakeholders. The respondents included a construction entrepreneur, contractor, an architect, a resident and a client, which in this case is a social housing association. All respondents have experience. In these semi-structured interviews, a main question was "what social values do you see as important in a dwelling renovation?" This question was asked to gain a broad overview of the different attitudes towards social sustainability and the values connected to it.

To discuss and evaluate social sustainability in renovation, a definition of social sustainability was established by a framework of seven core values put forward by the authors. The framework consists of a list of social values related to construction, found from DGNB, existing papers and selected certification systems including LEED and BREEAM. 
To validate and adjust these, five interviews were conducted with primary stakeholders, from which 32 different social values were identified.

The social part of the existing DGNB certification was allocated into this framework of seven core values. To ensure that social values are realised, indicators are used as tools to measure and prove the implementation of actions. The existing indicators of the DGNB certification were investigated and optimised according to coherence between the title and the content of the indicator, suitability for renovation, the possibility to make the indicator quantitative, and planning and implementation at the correct time in the process.

After having optimised the existing indicators, the certification was further examined for shortcomings in social sustainability solely using the 32 values identified in the interviews with the primary stakeholders. To address and eliminate these shortcomings, new indicators were developed.

\section{Findings}

In this research, a framework of social sustainability is defined. This forms an essential basis for the analysis of social sustainability in the existing DGNB certification and the development of new indicators. It is essential that this framework should not be a restriction for any of the stakeholders, but rather guidelines to reach consensus on what needs to be fulfilled to achieve the minimum level of social sustainability. The framework consists of Core Values, which are comprehensive and broad concepts of social sustainability. Grouped under the Core Values are the Social Values, which are more specific and individual values. The final seven core values shown below have been selected based on the ability to group most of the other values and with them.

(1) Safety: Relates to functions, which increase the safety in the building, the surrounding area and safety during the construction phase. (2) Health: Covers measures that include the temperature, cold drafts, ventilation, view and acoustics. Health also embraces the work environment during the construction phase. (3) Functionality: Relates to that installations and components are functioning, easily accessible and well-maintained. Further, the surrounding areas are also well-maintained. (4) Location: Relates to aspects such as external accessibility and local transport connections to surrounding areas. (5) Communication: Relates to openness and information sharing, during all the phases of construction. (6) Identity: Relates to architectonic quality, culture and image for both the building and the surrounding area. (7) Knowledge: Relates to user experience, education of the workers and development of skills.

The values are identified from the DGNB certification (Green Building Council Denmark, 2014), LEED and BREEAM certifications (BREEAM, 2016; Starrs \& Burrows, 2010), interviews with primary stakeholder, and existing literature (Ahmad \& Thaheem, 2016; Kylili, et al., 2016; Acre \& Wyckmans, 2014; Häkkinen, 2012; ALwear \& Clements-Croome, 2009; Sutherland, et al., 2016).

\subsection{Allocation of existing indicators in the DGNB certification}

An allocation was performed to create transparency, and to create a more systematic procedure for examining the certification for shortcomings in social sustainability. These were then by logical allocation divided into the seven core values.

For the analysis and optimisation of the existing indicators in the social pillar, five main steps were considered. The steps included coherence between the titles and the content of the suitability for renovation, the possibility to make the indicator quantitative and planning and implementation at the correct time. 
10th Nordic Conference Tallinn

\section{6}

Figure 1.

Core Values, Values and Qualities from Interviews and Indicators
Indicators are generally qualitative and cannot be made quantitative without the risk of losing validity, as this would require more data showing the relation between quantitative measures and the effects on social values. Coherence is an issue in several of the indicators. Further, it was seen that it was challenging to implement the indicators to renovation, but the assessed indicators were still relevant for renovation and therefore a few changes and additions were carried out in order to ensure applicability in renovation projects. In relation to time for planning the indicators, it proved necessary to move some of the indicators to other phases of the project process. In renovation, preconditions are different as the building is already on site and early investigation can improve the basis for future decisions. Additionally, all the legislative indicators were excluded from the analysis, as these are always required.

\subsection{Development of new indicators to the optimised DGNB certification}

After the analysis of the existing indicators, further examination of shortcomings in the certification was performed. 16 of the 32 social values identified in the five interviews are not addressed in the existing DGNB certification and are thus considered potential shortcomings. Each of these social values was found relevant as existing literature proved to address similarities in content. These values can be seen in the second column in Figure 1.

Then, to eliminate these shortcomings, new indicators were developed. In total 16 indicators are developed, as shown in the third column in Figure 1.

\subsection{Description of the newly developed indicators}

New indicators were developed to eliminate the shortcomings collected from the interviews and identified in the analysis. The new indicators were developed using different theories and methods as the conditions for eliciting the values were not the same. Each indicator is described in Table 2, where both the theoretical background, the phase of implementation and how to implement the indicator is described.

\begin{tabular}{|c|c|c|}
\hline Core values & Social Values & Indicators \\
\hline \multirow{3}{*}{ Safety } & \multirow{3}{*}{$\begin{array}{l}\text { Work environment } \\
\text { Social activities }\end{array}$} & Non-work related activities \\
\hline & & \\
\hline & & Screening of the constructability \\
\hline \multirow{2}{*}{ Health } & Constructability & Follow up meetings \\
\hline & \multirow{7}{*}{$\begin{array}{l}\text { Intermediation to } \\
\text { resident } \\
\text { Cooperation - } \\
\text { partnering } \\
\text { Good management } \\
\text { Encourage employees } \\
\text { Interaction } \\
\text { Communication } \\
\text { Flat organisation } \\
\text { Openness } \\
\text { Responsibility } \\
\text { Feedback }\end{array}$} & Common site meetings every week for problem solving \\
\hline \multirow[t]{2}{*}{ Functionality } & & $\begin{array}{l}\text { Feedback from residents, eliminiation of issues, and a report for furture } \\
\text { improvennents }\end{array}$ \\
\hline & & Intermediation of design choices with visuals \\
\hline \multirow{2}{*}{ Communication } & & Common cantina \\
\hline & & Open digital quality assurance from all parties of the construction \\
\hline \multirow{2}{*}{ Location } & & Historic analysis of the area, the building and architectural observations \\
\hline & & \begin{tabular}{|l}
$\begin{array}{c}\text { Description and quality assurance plan of the details either preserved or newly } \\
\text { added }\end{array}$ \\
\end{tabular} \\
\hline \multirow{2}{*}{ Identity } & \multirow{4}{*}{$\begin{array}{l}\text { Architectonic quality } \\
\text { Constant activity }\end{array}$} & Description of the materials \\
\hline & & Interior chosen by the residents \\
\hline \multirow{4}{*}{ Knowledge } & & Adapt and design a small area by residents \\
\hline & & Transition areas from private to public \\
\hline & Education & Constant activity by design \\
\hline & & Use of social clauses in the tender \\
\hline
\end{tabular}




\begin{tabular}{llll}
\hline New indicator & Theoretical background & Implementation phase & Suggestion for implementation \\
\hline Core Value: Health & & \\
\hline $\begin{array}{l}\text { Non-work related } \\
\text { activities }\end{array}$ & $\begin{array}{l}\text { (Beslin \& Reddin, 2004), } \\
\text { (Wong \& Cheung, 2004) }\end{array}$ & $\begin{array}{l}\text { Construction } \\
\text { The client has to arrange the } \\
\text { activities continuously during } \\
\text { the construction phase. These } \\
\text { social activities can be } \\
\text { everything from a football } \\
\text { tournament to a morning } \\
\text { breakfast }\end{array}$ \\
\hline
\end{tabular}

Core Value: Functionality

\begin{tabular}{|c|c|c|c|}
\hline $\begin{array}{l}\text { Screening of } \\
\text { constructability }\end{array}$ & (Ballard, 2000) & Before tender & $\begin{array}{l}\text { The client must invest in an } \\
\text { external screening of the } \\
\text { constructability of the existing } \\
\text { building }\end{array}$ \\
\hline Follow up meetings & (Ballard, 2000) & $\begin{array}{l}\text { Pre-project, design } \\
\text { and construction }\end{array}$ & $\begin{array}{l}\text { The client has to ensure that } \\
\text { follow-up meetings are on the } \\
\text { time schedule and master plan } \\
\text { updates are performed } \\
\text { continuously during the } \\
\text { construction }\end{array}$ \\
\hline
\end{tabular}

Core Value: Communication

Common site meetings every week

for problem solving

Feedback from residents, elimination of issues and a report for future improvements

Intermediation of design choices with visuals

Common cantina

(Christensen \& Parbst, 2009)

(Brunsgaard, 2011), (Ballard, 2000)

(Al-Kodmany, 1999)

Pre-design, design and construction

(Gambetta, 1988),

Open digital quality assurance from all partners of the (Wong \& Cheung, 2004) construction
Operation

Construction

Construction

Design and construction (requirement in the tender)
A weekly common site meeting for all workers on site to discuss smaller and simpler issues for solving A meeting with the residents two months after moving in to ensure correct use of the installation. Feedback summary sent to the contractors and designers for future improvements Visuals used by the designers as means to showcase and communicate design choices through either BIM models, virtual reality, mock-ups, etc.

The common cantina must be on-site and in a fair distance to reach for the workers around site. The eating area must be able to accommodate all the workers on-site at all times

The quality assurance should be stored online for all involved parties to access during the construction phase
Social Sustainability in Modelling

387

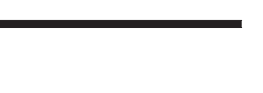

\section{.}




\section{0th Nordic Conference - Tallinn}

\section{8}

\begin{tabular}{lll} 
New indicator & Theoretical background & Implementation phase \\
\hline Core Value: Identity & & \\
\hline $\begin{array}{l}\text { Historic analysis of } \\
\text { the area, the building }\end{array}$ & $\begin{array}{l}\text { (Beim, 2012), (Nygaard, } \\
\text { 2002), (Bech-Nielsen, }\end{array}$ & Pre-design, design \\
$\begin{array}{l}\text { and architectural } \\
\text { observations }\end{array}$ & 1997)
\end{tabular}

Description and quality assurance plan of details either preserved or newly added

Description of the materials

(Vibæk Jensen \& Beim, 2006), (Nygaard, 2002), (Gehl, 2003)

Pre-design, design, construction

(Vibæk Jensen \& Beim, Design 2006)

(Vibæk Jensen \& Beim, $\quad$ Design

Interior chosen by the resident

Adapt and design small area by residents Transition areas from private to public

Constant activity by design

\section{6)} 2006)

(Gehl, et al., 2004), (Gehl, Design

2003), (Acre \&

Wyckmans, 2015)

(Gehl, 2003)
(Vibæk Jensen \& Beim, Design
Design

Suggestion for implementation

Assessing the architectural value of the building and the area through the SAVE model with a set of analysis measures related to style, area, time, typical expression and building method

A description of the details in the design split into finegrained and coarse-grained details together with a plan for the quality assurance

A report describing larger components both inside and outside. The components must be described with aging, details, texture, colour and composition

The residents choose the interior, within a scheme of choices

The residents adapt and design an area in the building or in the connected outdoor area A report with drawings proving how the transition areas are created A concept plan including drawings and an explanation of how the design supports activity at the site at all hours

Core Value: Education

Table 1. (Continued)
Use of social clauses (Konkurrence- og Before tender

in the tender $\quad$ Forbrugerstyrelsen, 2016)
A minimum of $10 \%$ of all the hired workforces must be under education

\section{Discussion}

In this research, a framework for social sustainability is established containing seven core values, which were identified from literature studies, existing sustainability certifications and five interviews with primary stakeholders. If the research had been extended with more interviews, they could possibly work as quantification for the results of this study. Furthermore, by extending the research, more than seven core values might have been found. Additional core values would not change the development of the new indicators identified in this paper as the new indicators are not developed from the core values, but identified from the five interviews. If more respondents had been interviewed, more values, which are not already assessed in the DGNB certification, would most likely be identified. These potential new values would then be in the need for further research and possibly development of additional indicators. 


\subsection{Allocation of the indicators eliciting a social value}

This research focuses on social sustainability and therefore environmental and economic sustainability has not been assessed. This limitation resulted in limitations regarding the intersection between the three parts of sustainability. This intersection has relevance as the indicators could, to some extent, be allocated differently by others. Furthermore, there is also an intersection and interdependence among the seven core values. However, to create an overview, each indicator is only grouped under one of the core values, corresponding to the value that the indicator primarily elicits.

\subsection{Developing new indicators for a holistic approach to social sustainability}

In a future examination of shortcomings, the values found, e.g. through interviews, must be allocated to the core values. If the values are not already addressed, the values must be analysed for relevance and new indicators that elicit the values should be developed. The process of first identifying whether the values are shortcomings in the existing DGNB certification become less substantial because of the structuring of the social sustainability into seven core values. If it is a shortcoming, it will still demand a systematic check through the whole certification, also including the environmental and economic pillars. However, if it is not a shortcoming, the researcher is more likely to find the indicator eliciting the value faster, since the systematic approach identifies the most likely placement first.

By creating more indicators, the certification will arguably be more extensive and complicated, but it is considered not an argument for not creating more indicators. It is suggested that the DGNB certification should be optimised regularly. This should be done as it most likely is not practically possible for a certification to incorporate a complete holistic approach as the field is constantly moving forward, and thus, there will always be ways to be even more sustainable. Therefore, the aim of developing a holistic sustainable certification should be to incorporate the most holistic approach possible given the current knowledge.

After having obtained a more comprehensive knowledge of the embodiment of sustainability, the authors are under the impression that there should not be developed a DGNB certification specific to dwelling renovation. All dwellings should be evaluated on one common scale of sustainability or else it will not be possible to compare the level of sustainability of renovation to newly build construction.

Some of the new indicators focus on the construction process and on the employees, which differ from the original DGNB system that focuses on adding value to the residents. This is a deliberate choice as it is believed that for a product or project to have a holistic approach to sustainability, all the process phases also have to be sustainable.

\section{Conclusion}

A number of shortcomings were identified which have led to the development of 16 new indicators. As the field of sustainability in construction is constantly moving forward, the contribution should not be seen as the final solution but as a step in the right direction.

To address the topic of this paper, it was necessary to establish a framework for social sustainability. This framework is defined based on seven core values. The existing indicators in the certification are grouped under the seven core values. This results in a more transparent and systematic structure that provides an easy overview for the user of the content.

It is recommended to continuously revise the certification to incorporate new knowledge by implementing new relevant indicators and excluding future legislative indicators. The systematic approach taken in this research is believed to be applicable to examine the DGNB 
10th Nordic Conference Tallinn certification for future shortcomings related to social sustainability. At all times, the aim of developing a holistic sustainable certification should be to incorporate the most holistic approach possible given the current knowledge. Furthermore, it is argued that it is not necessarily the best solution to have a dedicated certification system for renovation in addition to new construction as it should be possible to compare different building types on one common scale of sustainability.

\section{0}

\section{References}

Acre, F. \& Wyckmans, (2015). Dwelling renovation and spatial quality. The impact of the dwelling renovation on spatial quality determinants. International Journal of Sustainable Built Environment, 1(1), pp. 12-41.

Acre, F. \& Wyckmans, A., (2014). Spatial quality determinants for residential building renovation: A methodological approach the development of spatial quality assessment. International Journal of Sustainable Building Technology and Urban Development, 1(1), pp. 183-204.

Ahmad, T. \& Thaheem, M. J., (2016). Developing a residential building-related social sustainability assessment framework and its implications for BIM. Sustainable Cities and Society, 26(1-15), p. 16.

Ahn, C., Lee, S. \& Pena-Mora, F. A. S., (2010). Toward environmentally sustainable construction processes: The U.S. and Canada's perspective on energy consumption and GHG/CAP emission. Sustainability, 2, Volume 2, pp. 354-370.

Al-Kodmany, K., (1999). Using visualization techniques for enhancing public participation in planning and design: process, implementation, and evaluation. Landscape and Urban Planning, Volume 45, pp. 37-45.

ALwear, H. \& Clements-Croome, D., (2009). Key performance indicators (KPIs) and priority setting in using the multi-attribute approach for assessing sustainable intelligent buildings. Building and Environment, 26 08, pp. 790-807.

Ballard, G. H., (2000). The Last Planner System of Production Control, Birmingham: 2000.

Bech-Nielsen, G., (1997). SAVE - a critical analysis (Danish edition). 1 ed. Copenhagen: Miljø- og Energiministeriet, Skov- og Naturstyrelsen, Energiministeriet.

Beim, A., (2012). Arkitektonisk kvalitet og vardiskabelse. Renovering og energirenovering. Copenhagen, Kunstakademiets skoler for Arkitektur, Design og Konservering.

Beslin, R. \& Reddin, C., (2004). How leaders can communicate to build trust. [Online] Available at: http:// iveybusinessjournal.com/publication/how-leaders-can-communicate-to-build-trust/ [Accessed 08 December 2016].

BREEAM, (2016). BREEAM. [Online] Available at: http://www.breeam.com/ [Accessed 29 September 2016].

Brunsgaard, C., (2011). Understanding of Danish Passive Houses based on Pilot Project Comfort Houses (PhD Thesis), Aalborg: Aalborg University Department of Civil Engineering.

Bygherreforeningen, Maagøe, V.\& InnoBYG, (2013). Hvidbog om baredygtighed i byggeriet, Et overblik over eksisterende viden og nye initiativer, Denmark: Bygherreforeningen, Viegand Maagøe and InnoBYG.

Christensen, S. \& Parbst, K., (2009). Så tal dog sammen, Copenhagen: Forbyggelsesfonden and BAR.

Gambetta, D., (1988). Trust: Making and Breaking Cooperative Relations. 1 ed. Oxford: Basil Blackwell.

Gehl, J., (2003). Livet mellem husene. 6 ed. Copenhagen: Arkitektens forlag.

Gehl, J., Kaefer, L. J. \& Reigstad, S., (2004). Nærkontakt med huse. Arkitekten, 9(1), pp. 6-21.

Green Building Council Denmark, (2016). DK-GBC. [Online] Available at: http://www.dk-gbc.dk/dgnb/ [Accessed 21 November 2016]. 
Green Building Council Denmark, (2014). Etageejendomme og rakkehuse (Blocks of flats and townhouses). 1.1 ed. Denmark: Green Building Council Denmark.

Harling, P. L. \& Petersen, S., (2016). Institut for ingeniørvidenskab AU. [Online] Available at: http://eng. au.dk/en/news-and-events/news/show/artikel/au-skal-levere-forskning-til-historisk-stort-energiprojekt/ [Accessed 1303 2019].

Häkkinen, T., (2012). Sustainability and performance assessment and benchmarking of buildings, Espoo: VTT, JULIKAISIJA.

Konkurrence- og Forbrugerstyrelsen, (2016). Vejledning om sociale klausuler $i$ udbud, Copenhagen: Konkurrence - og Forbrugerstyrelsen.

Kylili, A., Fokaides, P. A. \& Jimenez, P. A. L., (2016). Key Performance Indicators approach in buildings renovation for the sustainability of the built environment: A review. Renewable and Sustainable Energy Reviews, 65(1), pp. 906-915.

Marjaba, G. \& Chidiac, S., (2016). Sustainability and resiliency metrics for buildings. A critical review. Building and Environment, 101(1), pp. 116-125.

Nielsen, A. N., Jensen, R. L., Larsen, T. S. \& Nissen, S. B., (2016). Early stage decision support for sustainable building renovation - A review. Building and Environment, 103(1), pp. 165-181.

Nygaard, E., (2002). Architectonic quality - an attempt at a brief definition. Nordisk Arkitekturforskning Forum, 15(1), pp. 91-96.

Starrs, M. \& Burrows, V. K., (2010). BREEAM versus LEED, Kings Langley: Inbuilt.

Sutherland, J. W. et al., (2016). The role of manufacturing in affecting the social dimension of sustainability. Elsevier, pp. 689-712.

Vallance, S., Perkins, H. C. \& Dixon, J. E., (2011). What is social sustainability? A clarification of concepts. Elsevier, Geoforum, 42, pp. 342-348.

Vibæk Jensen, K. \& Beim, A., (2006). Kvalitetsmål i den arkitektoniske designproces (Quality measures in the architectonic design process). 1 ed. Copenhagen: CINARK.

Wong, P. S.-P. \& Cheung, S.-O., (2004). Trust in construction partnering: views from parties of the partnering dance. Project Management, 22(1), pp. 437-446. 